\title{
Pemahaman Orang Tua terhadap Pola Makan Anak Penderita Kanker di RSUP Prof Dr. R. D. Kandou Manado
}

\author{
Ronald Rompies, Hubert I. Tatara, Stefanus Gunawan
}

\author{
Bagian Ilmu Kesehatan Anak Fakultas Kedokteran Universitas Sam Ratulangi Manado \\ Rumah Sakit Umum Pusat Prof. Dr. R. D. Kandou, Manado \\ Email: ronald.rompies@gmail.com
}

\begin{abstract}
Information about nutrition and parents' experience are very important in supporting the nutrition of children with cancer. This study was aimed to obtain the parents' understanding about nutrition of children with cancer. We used modified structured questionnaire about diet and sanitation which were already validation testing. The results showed that there were 38 complete questionnaires consisted of acute lymphoblastic leukemia (ALL) in 14 children (36.8\%), followed by acute myeloid leukemia (AML) in 8 children, and retinoblastoma in 7 children. The majority of parents were housewives (84\%) meanwhile senior high school educated was the most common education (57.8\% of mothers and 52.6\% of fathers)). All parents changed the diet style of their children after diagnosed as cancer. Most parents (78.9\%) answered that food could cause cancer, and $(94.7 \%)$ avoided certain foods; (78.9\%) chose junk food as avoided food; and during treatment, $(89.4 \%)$ gave special foods which were high protein, fruits, vegetables, and milk. Most parents $(94.7 \%)$ answered that children with cancer had to avoid street foods, and (94.7\%) chose mineral water as a safe drink. In conclusion, education of medical workers about nutrition of children with cancer is needed to achieve agreement in optimal nutrition.
\end{abstract}

Keywords: nutrition of children with cancer

\begin{abstract}
Abstrak: Informasi mengenai kebutuhan nutrisi dan pengalaman orang tua berperan penting dalam menunjang nutrisi anak dengan kanker. Penelitian ini bertujuan untuk mengetahui pemahaman orang tua tentang nutrisi yang optimal bagi anak dengan kanker. Pada penelitian ini digunakan kuesioner terstruktur tentang diet dan kebersihan yang dimodifikasi, teruji dengan validitas isi. Hasil penelitian mendapatkan 38 kuesioner yang diisi lengkap, dengan diagnosis terbanyak acute lymphoblastic leukemia (ALL) pada 14 anak (36,8\%), diikuti acute myeloid leukemia (AML) 8 anak, dan retinoblastoma 7 anak. Mayoritas orang tua memiliki pekerjaan ibu rumah tangga (84\%) dan pendidikan terakhir yang terbanyak ialah SMA (ibu 57,8\% dan ayah 52,6\%). Semua orang tua merubah pola makan anak mereka setelah terdiagnosis kanker. Sebagian besar orang tua $(78,9 \%)$ menjawab makanan dapat menyebabkan kanker dan $(94,7 \%)$ menghindari makanan tertentu; $(78,9 \%)$ memilih junk food sebagai makanan yang harus dihindari; dan $(89,4 \%)$ memberikan makanan khusus selama pengobatan mengandung tinggi protein, buah, sayur, dan susu. Sebagian besar orang tua $(94,7 \%)$ menjawab anak penderita kanker tidak boleh makan makanan di pinggir jalan, dan (94,7\%) memilih air mineral sebagai minuman yang aman untuk diminum. Simpulan penelitian ialah perlu dilakukan edukasi dan penyuluhan oleh tenaga medis tentang nutrisi untuk anak kanker agar terdapat kesepahaman dalam pemberian nutrisi yang optimal.
\end{abstract}

Kata kunci: nutrisi anak dengan kanker

\section{PENDAHULUAN}

Nutrisi merupakan salah satu aspek penting dalam menunjang keberhasilan terapi pada pasien dengan kanker. Saat ini, masih sering terjadi mispersepsi antara makanan yang dianjurkan untuk dikonsumsi 
oleh anak yang menderita kanker dengan makanan yang diberikan oleh orang tua mereka. $^{1,2}$ Pada penderita kanker, perlu diberikan perhatian lebih, terutama dalam pengobatan. Hasil penelitian menunjukkan bahwa makanan yang bergizi baik sebelum, selama, dan setelah pengobatan kanker memiliki keuntungan bagi penderita kanker, di antaranya dapat meningkatkan kualitas hidup, menjaga tetap sehat, membantu dalam mengurangi efek samping pengobatan kanker, menunjang keberhasilan terapi, serta meningkatkan sistem imun tubuh. ${ }^{3,4}$

Informasi mengenai kebutuhan nutrisi serta pengalaman orang tua berperan penting dalam menunjang nutrisi anak. Dengan pemahaman orang tua dan informasi yang memadai tentang nutrisi yang baik, perawatan anak dengan kanker akan lebih berkualitas. ${ }^{4}$ Seiring dengan perkembangan teknologi, informasi yang didapatkan oleh para orang tua tentunya bervariasi. Informasi tersebut perlu dikaji lebih mendalam, sehingga para orang tua tidak menerima informasi yang kurang tepat. Hal ini berhubungan dengan pemahaman orang tua akan makanan yang boleh dan tidak boleh diberikan pada anak dengan kanker. Berdasarkan latar belakang ini maka penelitian ini dilakukan untuk mengetahui seberapa jauh pemahaman dan pengetahuan orang tua akan nutrisi optimal bagi anak dengan kanker.

\section{METODE PENELITIAN}

Jenis penelitian ini ialah deskriptif dengan desain potong lintang. Populasi penelitian ini ialah semua orang tua dari anak yang dirawat di ruang Pusat Kanker Anak Estella Bagian Ilmu Kesehatan Anak RSUP Prof. Dr. R. D. Kandou Manado, sejak bulan Januari 2020 - Februari 2020. Kriteria inklusi penelitian ini ialah pasien yang terdiagnosis kanker, berusia kurang dari 18 tahun, dan sementara dalam kemoterapi maupun yang dirawat karena komplikasi terapi. Pada penelitian ini diikutsertakan sebanyak 45 anak.

Orang tua tinggal bersama dengan pasien di Ruangan Estella selama kemoterapi. Tenaga medis memberikan kuesioner yang telah dimodifikasi dari kuesioner yang digunakan Sidharth et al. ${ }^{1}$ Orang tua diberikan kesempatan untuk mengisi kuesioner sesuai dengan pemahaman dan pengetahuan mereka tentang nutrisi yang baik bagi anaknya. Status pendidikan orang tua dicatat dan diklasifikasi sesuai dengan strata pendidikan di Indonesia, yaitu: lulus sekolah dasar, sekolah menengah pertama, sekolah menengah atas, dan lulus sarjana. Usia, jenis kelamin, dan diagnosis pasien dicatat.

\section{HASIL PENELITIAN}

Pada penelitian ini didapatkan sebanyak 38 orang tua yang telah mengisi kuesioner dengan lengkap. Sebanyak 7 kuesioner telah di eksklusi dari penelitian dikarenakan orang tua tidak mengisi kuesioner dengan lengkap. Tabel 1 memperlihatkan data karakteristik anak dengan kanker yang dirawat di ruang Estella RSUP Prof. Dr. R. D. Kandou Manado periode Januari sampai Februari 2020 dan pengisian kuesioner yang lengkap. Didapatkan anak berjenis kelamin laki-laki (22 anak) lebih banyak daripada perempuan (16 anak) (57,9\% vs $42,1 \%$ ). Rentang usia rerata anak kanker terbanyak pada usia 5-10 tahun yaitu 17 anak (44,7\%), disusul anak usia lebih dari 10 tahun yaitu 12 anak $(31,6 \%)$, dan di bawah usia 5 tahun yaitu 9 anak $(23,7 \%)$.

Tabel 1. Distribusi anak kanker menurut jenis kelamin dan rentang usia

\begin{tabular}{lcc}
\hline Karakteristik & $\begin{array}{c}\text { Jumlah } \\
(\mathbf{n})\end{array}$ & $\begin{array}{c}\text { Persentase } \\
(\%)\end{array}$ \\
\hline Jenis kelamin & & \\
Laki-laki & 22 & 57,9 \\
Perempuan & 16 & 42,1 \\
Rentang usia & & \\
$<5$ thn & 9 & 23,7 \\
5-10 thn & 17 & 44,7 \\
10 thn & 12 & 31,6 \\
\hline
\end{tabular}

Gambar 1 memperlihatkan anak dengan diagnosis ALL yang terbanyak (14 anak), diikuti AML pada 8 anak, retinoblastoma pada 7 anak, serta osteosarkoma dan anemia hemolitik masing-masing sebanyak 3 anak. 


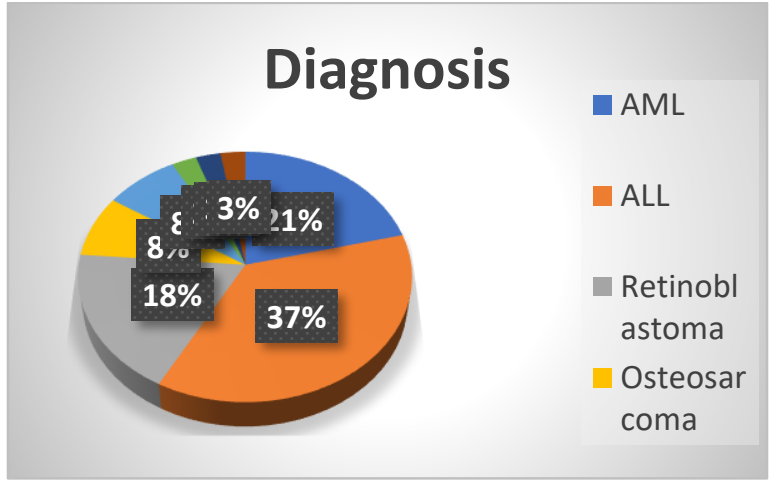

Gambar 1. Distribusi pasien anak dengan kanker menurut diagnosis

Tabel 2 memperlihatkan bahwa usia 30 sampai 39 tahun merupakan usia terbanyak baik pada ibu $(52,6 \%)$ maupun pada ayah $(57,9 \%)$. Ibu rumah tangga merupakan pekerjaan terbanyak ibu, sekitar 32 orang $(84,2 \%)$, dan sebagai petani pada ayah sekitar $16(42,1 \%)$. Berdasarkan tingkat pendidikan, lulusan SMA terbanyak, baik ibu 22 $(57,8 \%)$ maupun ayah $20(52,6 \%)$. Tingkat pendapatan kedua orang tua,yang menjawab 1-2 juta sebanyak 10 orang (26,3\%), meskipun terdapat sekitar 12 orang tua $(31,6 \%)$ yang tidak ingin memberitahukannya.

Gambar 2 memperlihatkan bahwa dari hasil kuesioner yang telah diisi oleh para orang tua dari anak kanker, sebanyak 30 orang tua $(78,9 \%)$ menjawab makanan dapat menyebabkan terjadinya kanker pada anak.

Gambar 3 memperlihatkan bahwa 14 orang tua $(36,8 \%)$ berpendapat bahwa junk food menjadi penyebab tersering untuk terjadinya kanker, diikuti sekitar 7 orang tua $(18,4 \%)$ dan 5 orang tua $(13,1 \%)$ yang menyatakan bahwa makanan yang menggunakan bahan pengawet dan bahan penyedap rasa menjadi penyebab kanker. Semua orang tua $(100 \%)$ merubah pola makan anak mereka setelah terdiagnosis kanker. Sebanyak 36 orang tua $(94,7 \%)$ menjawab harus menghindari jenis makanan tertentu pada saat anak mereka sedang dalam pengobatan.

Gambar 4 memperlihatkan bahwa menurut orang tua, jenis makanan yang harus dihindari ialah junk food $(78,9 \%)$, diikuti makanan yang mengandung bahan pengawet $(18,4 \%)$ dan yang mengandung bahan penyedap $(13,1 \%)$.
Tabel 2. Distribusi karakteristik orang tua dari anak dengan kanker

\begin{tabular}{|c|c|c|}
\hline Karakteristik & $\begin{array}{c}\text { Jumlah } \\
\text { (n) }\end{array}$ & $\begin{array}{c}\text { Persentase } \\
(\%)\end{array}$ \\
\hline \multicolumn{3}{|l|}{ Ibu } \\
\hline \multicolumn{3}{|l|}{ Usia } \\
\hline $20-29$ thn & 10 & 26,3 \\
\hline $30-39$ thn & 20 & 52,6 \\
\hline$\geq 40$ thn & 8 & 21,1 \\
\hline \multicolumn{3}{|l|}{ Pekerjaan } \\
\hline IRT & 32 & 84,2 \\
\hline Swasta & 3 & 7,9 \\
\hline Guru & 1 & 2,6 \\
\hline Honorer & 2 & 5,3 \\
\hline \multicolumn{3}{|l|}{ Pendidikan } \\
\hline SD & 5 & 13,1 \\
\hline SMP & 8 & 21,1 \\
\hline SMA & 22 & 57,8 \\
\hline Sarjana & 3 & 8,0 \\
\hline \multicolumn{3}{|l|}{ Ayah } \\
\hline \multicolumn{3}{|l|}{ Usia } \\
\hline $20-29$ thn & 6 & 15,8 \\
\hline $30-39$ thn & 22 & 57,9 \\
\hline$\geq 40$ thn & 10 & 26,3 \\
\hline \multicolumn{3}{|l|}{ Pekerjaan } \\
\hline Petani & 16 & 42,1 \\
\hline Buruh & 3 & 8,0 \\
\hline Sopir & 6 & 15,8 \\
\hline PNS & 1 & 2,6 \\
\hline Swasta & 12 & 31,5 \\
\hline \multicolumn{3}{|l|}{ Pendidikan } \\
\hline SD & 7 & 18,4 \\
\hline SMP & 9 & 23,7 \\
\hline SMA & 20 & 52,6 \\
\hline Sarjana & 2 & 5,3 \\
\hline \multicolumn{3}{|l|}{ Pendapatan orang } \\
\hline$<1$ juta & 10 & $\begin{array}{l}10,4 \\
26,3\end{array}$ \\
\hline $1-2$ juta & 5 & 13,2 \\
\hline 2-3 juta & 4 & 10,5 \\
\hline$>3$ juta & 12 & 31,6 \\
\hline Tidak menjawab & & \\
\hline
\end{tabular}

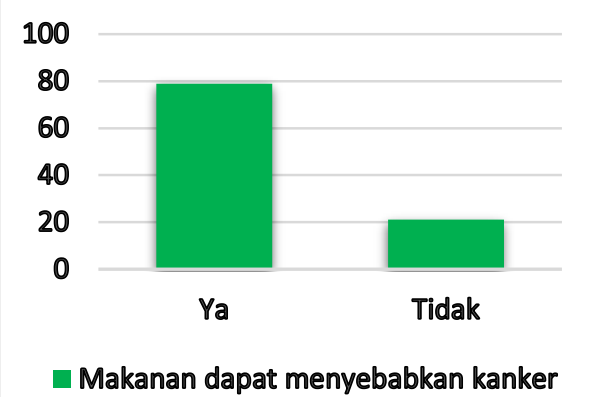

Gambar 2. Makanan yang dapat menyebabkan kanker 


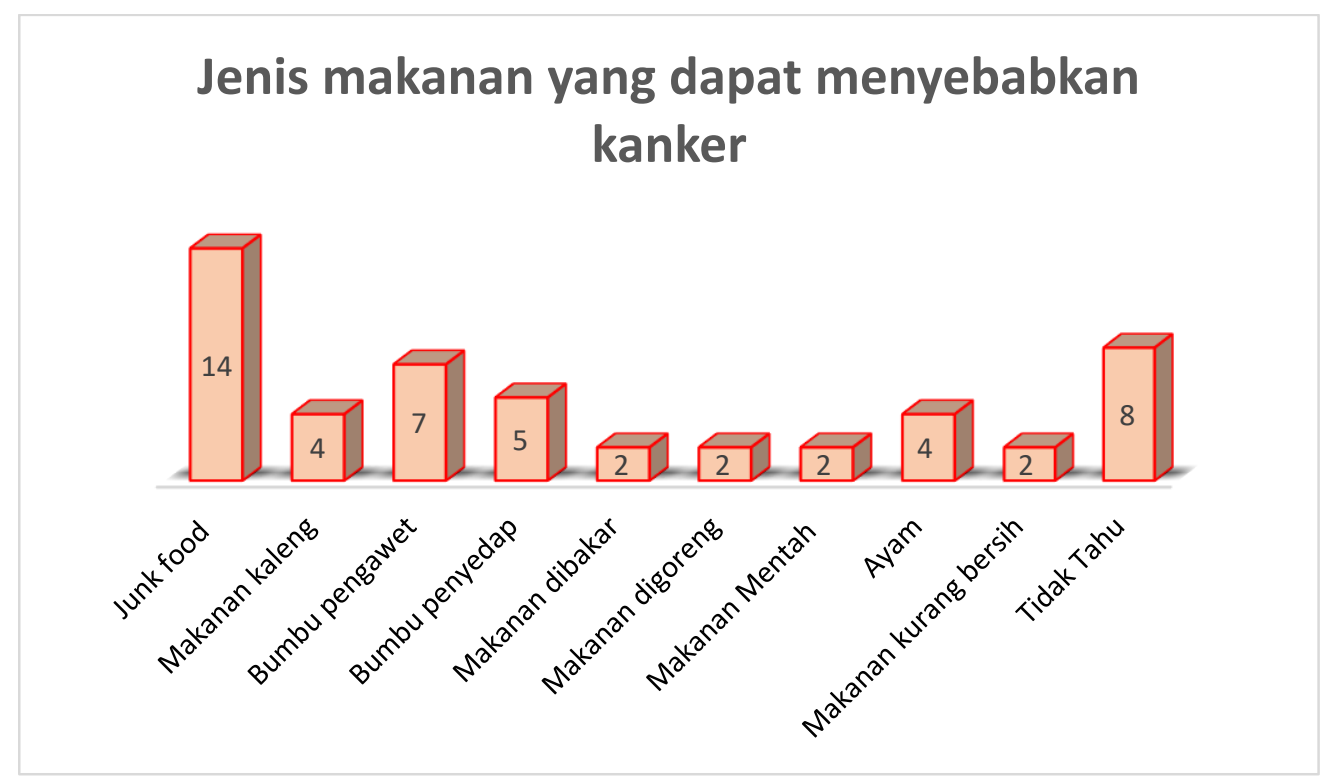

Gambar 3. Jenis makanan yang dapat menyebabkan kanker

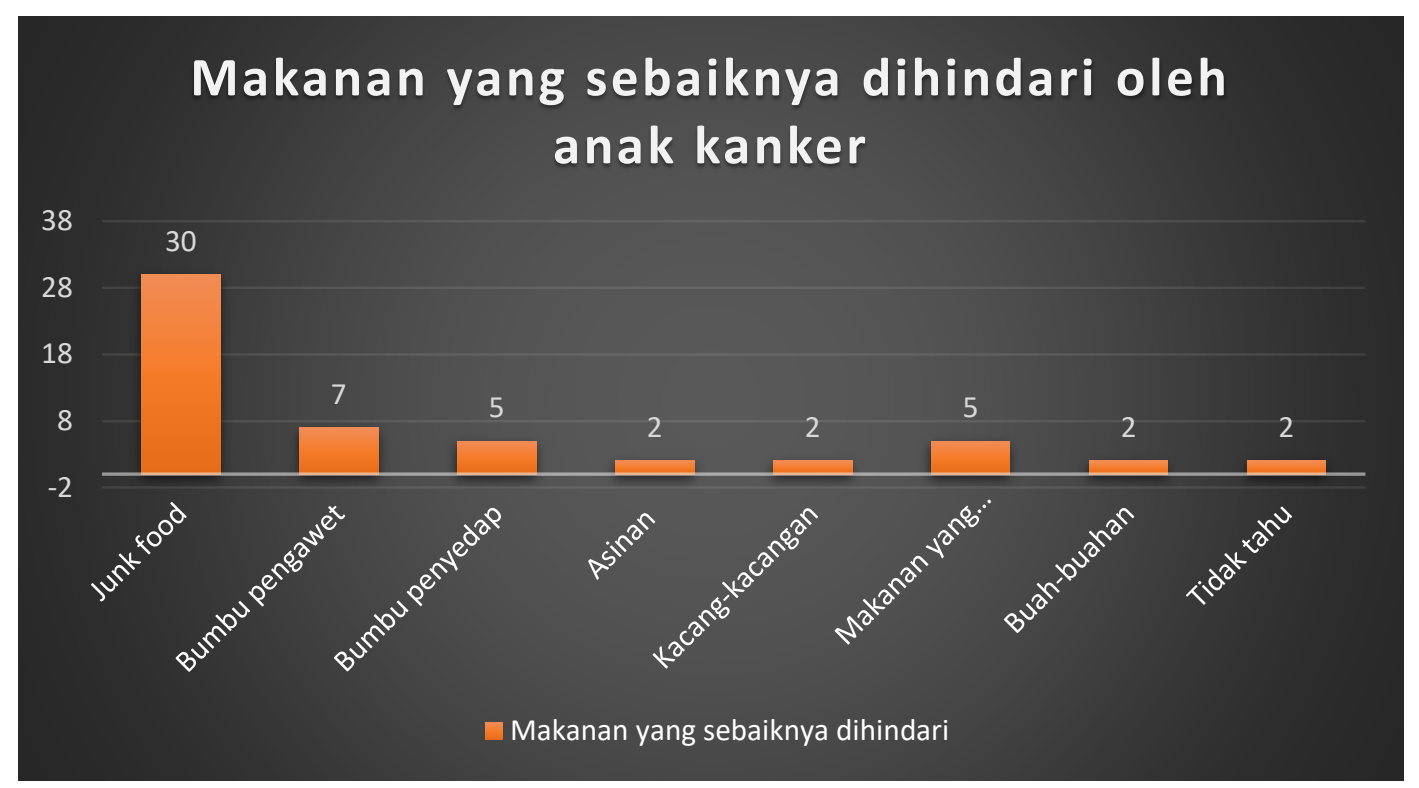

Gambar 4. Makanan yang sebaiknya dihindari oleh anak kanker

Orang tua juga diberikan pertanyaan apakah terdapat makanan yang dapat meningkatkan sel darah putih (leukosit), dan didapatkan 34 orang tua menjawab ada makanan tertentu yang dapat meningkatkan leukosit, di antaranya roti tawar, sayuran, buah-buahan, kacang, dan telur. Ikan (18 orang) menjadi makanan pilihan dari para orang tua untuk meningkatkan leukosit pada anak.

Sebanyak 2 orang tua memperbolehkan anak mereka untuk jajan di pinggir jalan, sedangkan sisanya $(94,7 \%)$ melarang. Air mineral $(94,7 \%)$ menjadi pilihan orang tua untuk dikonsumsi bagi anak mereka, diikuti susu $(31,5 \%)$, jus buah-buahan $(15,7 \%)$, dan minuman manis $(0,03 \%)$.

Para orang tua kemudian diberikan pertanyaan seputar makanan yang akan dikonsumsi selama pengobatan kanker, dan sebanyak 30 orang $(78,9 \%)$ menjawab bahwa daging dapat dikonsumsi selama pengobatan, serta 34 orang menjawab susu dan olahan susu tidak harus dihindari selama pengobatan. 


\section{BAHASAN}

Hasil berbagai penelitian menunjukkan bahwa makan makanan yang bergizi pada sebelum, selama, dan setelah pengobatan kanker dapat memberikan dampak positif bagi penderita kanker. ${ }^{3,4}$

Saran dan edukasi tentang pola makan bagi anak kanker berbeda-beda baik dari dokter maupun dari ahli gizi. Begitu pula dengan semakin berkembangnya teknologi sehingga para orang tua dapat mengakses informasi dari berbagai sumber, misalnya dari internet, dari pendapat kolega dan teman mereka, serta dari tradisi dan budaya mereka. ${ }^{1,5}$

Terapi nutrisi yang optimal akan memberikan luaran yang bagus. Terapi ini juga tidak memerlukan biaya yang mahal, sehingga cocok untuk perawatan supportif. Berbeda halnya dengan di negara berkembang, yaitu petugas kesehatan dihadapkan dengan kondisi nutrisi pasien yang kurang baik. Hal ini dipengaruhi oleh kondisi infrastruktur. ${ }^{9}$

Hubungan antara makanan dan kanker sangat kompleks. Terdapat berbagai jenis kanker dan penyebabnya. Sebagian besar penyebabnya masih belum diketahui secara pasti, namun gaya hidup dan makanan kadang berperan dalam hal ini. ${ }^{3}$ Pada penelitian ini didapatkan sebanyak 30 orang tua $(78,9 \%)$ berpendapat bahwa makanan dapat menyebabkan terjadinya kanker.

Dari hasil penelitian, didapatkan bahwa semua orang tua dari anak yang dirawat di ruang Estella merubah pola makan anaknya setelah terdiagnosis kanker. Goddard et $\mathrm{al}^{6}$ mendapatkan adanya perubahan dalam pemberian asupan makan selama pengobatan, namun dengan asupan yang kurang bergizi.

Makan makanan yang bergizi setelah terdiagnosis kanker akan membantu dalam mempersiapkan kelanjutan pengobatan dan perawatan. Beberapa pasien mengalami kesulitan bahkan bermasalah untuk memilih makanan. Untuk menjaga agar berat badan tidak menurun, maka fleksibilitas terhadap pemilihan makanan diperlukan meskipun belum ada data yang membuktikan bahwa makanan khusus dapat menyembuhkan atau mengontrol kanker tersebut. ${ }^{3}$
Pada penelitian ini didapatkan 22 orang tua menjawab buah-buahan menjadi makanan yang sebaiknya ditambahkan dalam asupan nutrisi dari anaknya. Beberapa penelitian telah menjelaskan bahwa diet kaya akan buah dan sayur-sayuran, baik yang ditanam secara konvensional maupun yang secara organik, menjadi makanan penting dalam menurunkan risiko kanker. ${ }^{8}$

Beaulieu-Gagnon et $\mathrm{al}^{7}$ meneliti tentang kebiasaan makan dari anak sementara menjalani pengobatan kanker yang ditelaah dari beberapa sumber dan melaporkan adanya hubungan antara asupan makanan dengan nafsu makan yang rendah. Hasil wawancara terhadap 29 orang tua memperlihatkan bahwa salah satu faktor yang memengaruhi kebiasaan makan dari para anak, yakni rasa dari makanan itu sendiri.

Diet dibatasi pada pasien yang akan menjalani kemoterapi maupun pada transplantasi sumsum tulang. Pembatasan diet ini dikenal dengan konsep diet neutropeni, yang bertujuan untuk mencegah patogen penyebab infeksi masuk ke dalam tubuh melalui makanan. ${ }^{1}$ Pada penelitian ini, sekitar 94,7\% orang tua melarang untuk makan makanan yang tidak bersih, terutama yang berasal dari makanan di pinggir jalan.

Pembatasan makanan dikarenakan anak mengalami neutropenia, maupun ketakutan infeksi yang akan diderita bila memberikan makanan yang tidak sesuai, menyebabkan beberapa orang tua frustasi sehingga memengaruhi asupan makan, Dalam meningkatkan pemberian nutrisi perlu untuk mempertimbangkan beberapa aspek, diantaranya penyakit yang diderita, fase saat perawatan, referensi makanan yang diberikan, serta pengetahuan dan kepercayaan dari orang tua. Pertimbangan ini diperlukan untuk meningkatkan kebiasaan diet anak. Pemahaman dan persepsi yang baik dari para orang tua, akan membantu tenaga kesehatan dalam merawat dan memberikan terapi. ${ }^{7}$

Edukasi tentang pemberian makanan yang adekuat dan menarik perlu diberikan kepada orang tua. Selain itu diperlukan juga pengetahuan tentang pilihan makanan pada anak serta makanan yang aman untuk dikonsumsi. ${ }^{10}$ Edukasi dan penyuluhan oleh 
tenaga medis tentang nutrisi pada anak kanker juga diperlukan agar terdapat kesepahaman dalam pemberian nutrisi optimal yang dibutuhkan.

\section{SIMPULAN}

Orang tua dari anak penderita kanker perlu diberikan edukasi dan penyuluhan oleh tenaga medis tentang nutrisi untuk anak dengan kanker agar terdapat kesepahaman dalam pemberian nutrisi yang optimal.

\section{Konflik Kepentingan}

Penulis menyatakan tidak terdapat konflik kepentingan dalam studi ini.

\section{DAFTAR PUSTAKA}

1. Sidharth T, Venkatraman R, Harshvardhan A, Praveen KS, Prasanth G, Trivadi SG, et al. Dietary perceptions and beliefs among families with children undergoing therapy for cancer. Pediatric Hematol Oncol J. 2017;2:25-8.

2. The American Cancer Society medical and editorial content team. Nutrition for children with cancer. American cancer society. [cited 2020 Feb 06]. Available from: https://www.cancer.org/treatment /children-and-cancer/when-your-childhas-cancer/nutrition/why-nutrition-isimportant.html.

3. Bruce J. Nutrition and cancer: a guide for people with cancer, their families and friends. Cancer Council Australia. 2019;1-68.
4. Arpaci T, Toruner E, Altay N. Assessment of nutritional problems in pediatric patients with cancer and the information needs of their parents: a parental perspective. Asia-Pacific J Oncol Nurs.2018;5:231-6.

5. Braun LE, Chen H, Frangoul H. Significant inconsistency among pediatric oncologists in the use of the neutropenic diet. Pediatr Blood Cancer 2014;61:1806-10

6. Goddard E, Cohen J, Bramley L, Wakefield CE, Beck EJ. Dietary intake and diet quality in children receiving treatment for cancer. Nutrition Reviews. 2019;77(5):267-77.

7. Beaulieu-Gagnon S, Belanger V dan Marcil V. Food habits during treatment of childhood cancer: a critical review. Nutr Res Rev. 2019;32(2):265-81.1-17.

8. American Institute for Cancer Research. Heal well: A cancer nutrition guide. 2013. [cited 2020 Mar 12]. Available from: https://www.aicr.org/news/aicrpartners-with-meals-to-heal-livestrongto-produce-free-nutrition-resource-forcancer-patients/

9. Ladas EJ, Arora B, Howard S, Roger P, Mosby T, Barr RD. A framework for adapted nutritional therapy for children with cancer in low and middle-income countries: a report from the SIOP PODC Nutrition Working Group. Pediatr Blood Cancer. 2016;63:1339-48.

10. Nasar S, Djoko S, Hartati SA, Budiwiarti YE. Penyakit keganasan. In: Penuntun Diet Anak (3rd ed). Jakarta: Fakultas Kedokteran Universitas Indonesia, 2017; p. 180-9. 